\title{
Building Employee Performance: Analysis Discipline and Commitment (A Case Study at UPI Convention Center Padang)
}

\author{
Muhammad Ridwan
}

Student of Master in Management Program, Universitas Putra Indonesia YPTK Padang, Indonesia

DOI:10.36348/SJHSS.2019.v04i09.006

| Received: 13.09.2019 | Accepted: 20.09.2019 | Published: 30.09 .2019

*Corresponding author: Muhammad Ridwan

\section{Abstract}

This study aims to determine the effect of labor discipline and commitment to employee performance UPI convention center of Padang. This research was conducted in the environment UPI Padang convention center. The population in this study were all employees of the environment UPI Padang convention center. Samples were 30 people with porposional techniques. The type and source of research data consist of primary data is data obtained from the opinions of the respondents through the questionnaire research and secondary data is data obtained from UPI convention center Padang Data analysis techniques used in the research hypothesis testing is a multiple linear regression analysis using SPSS version 25.0.

Keywords: Discipline of work, commitment, and employee performance.

Copyright @ 2019: This is an open-access article distributed under the terms of the Creative Commons Attribution license which permits unrestricted use, distribution, and reproduction in any medium for non-commercial use (NonCommercial, or CC-BY-NC) provided the original author and source are credited.

\section{INTRODUCTION}

Currently, Indonesia has evolved into a destination country for business and leisure. This was evidenced by the acquisition of data from the Statistical Report on Visitor arrivals to Indonesia 2004-2006, stating that tourist arrivals for meetings, incentives, conventions and exhibitions or meetings, incentive, convention, exhibition (MICE) reached $41.23 \%$, while for leisure travelers $56.49 \%$ and others $2.28 \%$. MICE (meeting, incentive, convention, and exhibition) as part of the tourism industry increasingly play a role in the tourism industry and the Asia Pacific region, including Indonesia that region's rapid growth and the MICE industry has great potential.

In Padang, West Sumatra, there is a university that has the facilities and infrastructure of convention, exhibition and sports venues are complete: University Putra Indonesia YPTK Padang, UPI Convention Center. Until now UPI Convention Center has managed to become one of the best convention center, because it can be seen from the interest of the customer to use the UPI Convention Center.

As the most important capital, functions and roles of the employees always aim to maximize productivity and efficiency through an effective way of working. Many factors affect the performance of employees in both internal factors are the factors that comes from within the employee such as motivation, competence, commitment, attitude and external factors, factors that come from outside employees are encouraged, such as compensation, leadership, work environment, organizational culture, labor discipline, training, work climate, supervision and so on. One of the efforts is taken by the organization to create the situation by providing a satisfactory compensation of employees.

On the other hand labor discipline is very important for the growth of the company, used mainly to motivate employees to be able to discipline himself in carrying out the work either individually or in groups. Besides helpful discipline to educate employees in this case the employee to comply with and please the rules, procedures, and policies exist, so it can produce a good performance. Factors discipline holds a very important role in the implementation of the employment. If the employee works with high discipline, the employee will be working with a high commitment to use all my abilities (competencies) that they have to produce a high performance to achieve organizational objectives which they work.

Another important factor is the employees' commitment to the company. Currently the organization's commitment can be the basis of competitiveness (competitive advantages), for 
organizations or companies with employees who commit will get advantages that are not owned by the organization or any other company. Factors that affect the organization's commitment to include individual characteristics, job characteristics, and work experience. Commitment to the organization itself has three components, namely a strong conviction of the person and the acceptance of organizational goals, willingness to try hard to rely on the organization, and a limited one's desire to maintain membership.

Although recognized by many parties working discipline and commitment is an important factor in the performance of employees, but in practice not all employees and companies are able to make it happen. One example is an employee who is in UPI Convention Center. From the results of preliminary observations obtained phenomena as follows:

- There are complaints from several employees in the work

- There are employees who are not disciplined in carrying out the task

- There are employees often return quickly

- There are employees are late for work

- There are employees who go out without an official permit

From the description above it can be stated that the employee's performance UPI Convention Center is still not optimal due to some of the things some of them, namely, discipline and commitment to the organization.

Based on the above background, the purpose of this study, namely:

- Analyzing the Effect of the discipline of work on employee performance at UPI Convention Center Padang partially.

- Analyzing the Effect of commitment on employee performance at UPI Convention Center Padang partially.

- Analyzing the Effect of labor discipline and commitment on employee performance at UPI Convention Center Padang simultaneously.

\section{LITERATURE REVIEW \\ Performance}

Performance which is the ratio between the real work with labor standards set out in performing their duties, Soedjono [1]. The success of an institution is strongly influenced by the performance of employees, due to the good performance would bring good results.

Performance can be seen as the process and results of the work. Performance is a process of how the work was going to accomplish the work. But the results also show the performance itself, Wibowo [2]. Presentation of the work is a result of one's work achieved in completing the work assigned to him. Performance means someone's achievement with regard to the task assigned to him.

According to Mangkunagara [3] suggests that the performance is the result of the quality and quantity of work accomplished by an employee in performing their duties in accordance with the responsibilities given to him. Performance indicators: quality of work, quantity of work, the implementation of tasks, and responsibilities.

\section{Discipline}

Nitisemito [4] suggests the discipline as an attitude, behavior and act in accordance with the regulations of the company, whether written or not tertulis. Dimension used in assessing the discipline of an employee of each company is different.

Discipline is a procedure to correct or punish subordinates for violating the rules or procedures, Simamora [5]. Discipline is essentially a restriction of freedom of employees. Discipline in a company can be established if a majority of the rules - the rules are adhered to by the bulk of the employees.

Labor discipline is defined as a tool used by managers to communicate with employees so that they are willing to change something behaviors as well as an effort to raise awareness and willingness to comply with all regulatory agencies and the prevailing social norms, Rival [6]. Indicators to measure employee discipline are: adhere to the rules and norms, the presence or absence, and complete the task on time.

\section{Commitment}

Employees with a strong affective commitment remain in the organization for wanting. Employees with continuant strong commitment to remain in the organization as needed. While employees who have a strong normative commitment remain in the organization because they have to do, Allen [7].

Furthermore, Porter [8] defined organizational commitment as the relative strength of the individual against an organization and its involvement in a particular organization, which is characterized by three psychological factors: (1) A strong desire to remain a member of an organization, (2) The desire to bend over backwards for the sake of the organization, and (3) Trust definite and acceptance of the values and goals of the organization.

Arikunto [9] also says that employees who have a strong commitment to always do more for the organization as well as other working friends and also do not mind to work beyond the working hours that have been determined. Indicators of employee commitment to the tasks include: caring, responsibility, loyalty, and passion to develop them selves. 


\section{Conceptual Framework}

Nawawi [10] argued about discipline is a conscious willingness to comply with any regulations that apply to the organization consciously of working. WIlingness is no element of coercion among people to obey all the rules organisasi. Discipline regarded as a prerequisite for the course of all activities in order realizing the organization's goals.

Chatz [11] stated that the commitment is the most fundamental thing for everyone in their profession. The success of wrestle someone in a given task to him is determined by how the commitment to the task and the level of education or knowledge possessed.

Based on previous research and from the various theories of experts then frame of mind in this study are as follows:

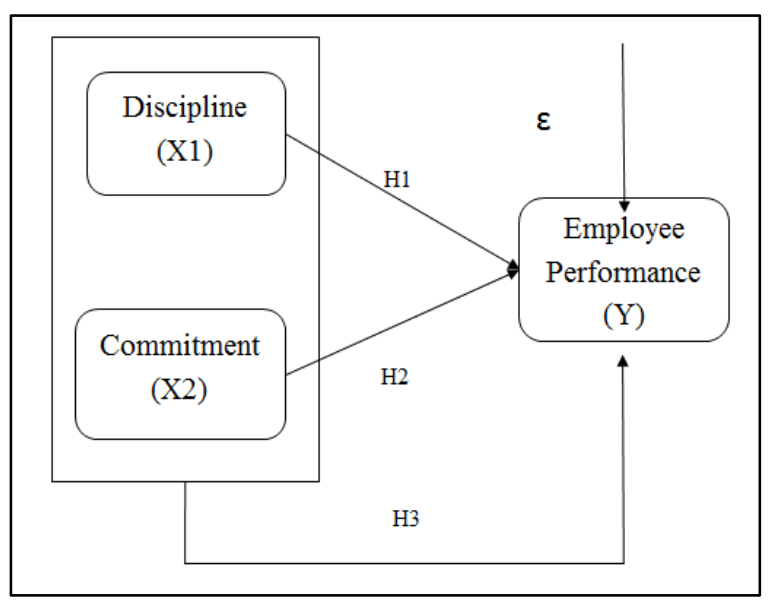

Fig-1: Framework of Thinking

\section{Research Hypothesis}

Based on the theoretical basis and framework hypothesis can be formulated as follows:

- H1) Discipline has positive and significant effect on employee performance at UPI Convention Center Padang partially.

- H2) Commitment has positive and significant effect on employee performance at UPI Convention Center Padang partially.

- H3) Discipline and commitment have positive and significant effect on employee performance at UPI Convention Center Padang simultaneously,.

\section{METHODS}

The method used in this study is a survey method. The method according Sugiyono [12] Survey is a study conducted on large populations and small, but the data studied are data from a sample taken from the population, so that the events can be found relative, distributive, and relationships between variables, sociological, and psychological while the form of research is a descriptive study. Descriptive research is studying the issue of descriptive problems in society, as well as the procedure applicable in the community and specific situations, including on relations activities, attitudes, views, as well as ongoing prosesyang processes and effects of the phenomenon.

Descriptive study was conducted using correlation techniques. This technique is performed to analyze the relationship between two independent variables namely labor discipline (X1) and commitment (X2) and one dependent variable is the performance of the employee (Y1). The population in this study is all employees working at UPI Convention Center Padang with total 30 employees. In this study establishes a sample of 30 permanent employees. This study uses Multiple Linear Regression equation: $\mathrm{Y}=\alpha+\beta 1 \mathrm{X} 1+$ $\beta 2 \mathrm{X} 2+\mathrm{e}$. Data analysis tools using SPSS version 25.0 for Windows. Then proceed with the analysis of the analysis test of determination ( $\mathrm{R}$ Square), partial hypothesis testing (t test) and simultaneous (F test) with an error tolerance level of 5 percent.

\section{RESULT AND DISCUSSION \\ Respondents Answer}

Based on respondents' answers can be given a description associated with the variables in the study, namely:

- Based on the scores and the percentage of work discipline variables are in very high category. The results of the respondents indicated that employee work discipline is already good.

- Based on the scores and the percentage for the variable of commitment are in very high category. The results of the respondents indicate that organizational commitment UPI Convention Center is already good.

- Based on the scores and the percentage for the variable performance of employees are in very high category. The results of the respondents indicated that employee performance at UPI convention center is already good.

\section{Multiple Linear Regression Analysis}

Multiple linear regression analysis was used to test the hypothesis of partial and simultaneous independent variable on the dependent variable. Based on the multiple linear regression coefficients with SPSS 25.0 obtain the results as Table- 1 below:

Table-1: Results of Multiple Linear Regression Analysis

\begin{tabular}{|c|l|c|r|}
\hline \multicolumn{2}{|c|}{ Model } & \multicolumn{2}{c|}{$\begin{array}{c}\text { Coefficients } \\
\text { unstandardized }\end{array}$} \\
\cline { 3 - 4 } \multicolumn{2}{|c|}{} & B & \multicolumn{1}{|c|}{ Std. Error } \\
\hline \multirow{2}{*}{1} & (Constant) & 3603 & 5,783 \\
\cline { 2 - 4 } & DISCIPLINE & 0,353 & 0,127 \\
\cline { 2 - 4 } & COMMITMENT & 0,397 & 0,055 \\
\hline
\end{tabular}

a. Dependent Variable: PERFORMANCE 
From Table-1 above we get the results of multiple linear regression equation: $\mathrm{Y}=\alpha+\beta 1 \mathrm{X} 1+$ $\beta 2 \mathrm{X} 2+\mathrm{e}=3.603+0,353 \cdot \mathrm{X} 1+0,397 . \mathrm{X} 2+\mathrm{e}$. With the caption description: $\mathrm{Y}=$ Employees Performance; $\mathrm{X} 1=$ Discipline, $\mathrm{X} 2$ = Commitment. From this equation can be defined: 1) variable Discipline and Commitment has a positive coefficient direction for the Employee Performance; 2) The value of the constant shows the influence of the variables $\mathrm{X} 1$ and $\mathrm{X} 2$, when $\mathrm{X} 1$ raise one unit will affect the unit in a variable $Y$.

Analysis of Determination (R Square)

For contributions Discipline (X1) and Commitment (X2) variable employee performance can be seen from the coefficient of determination $\mathrm{R} 2$ as shown in Table 2 below:

Table-2: Model Summary

\begin{tabular}{|c|c|c|c|c|}
\hline Model & $\mathbf{R}$ & R Square & Adjusted R Square & Std. Error of the Estimate \\
\hline 1 & $.868 \mathrm{a}$ & .753 & .735 & 2,967 \\
\hline
\end{tabular}

$\mathrm{R}$ value of 0.868 indicates a multiple correlation (discipline and commitment) with employee performance. Considering the variation of the value of $\mathrm{R}$ Square of 0.753 which indicates the role or contribution of discipline and commitment variables that can affect employee performance variable 75.3 percent and the remaining 24.7 percent is influenced by other variables. Employee performance is influenced by the competence and promotion, Ansori [13]. Employee performance is influenced by the transformational leadership style, training on work motivation, Paijan [14].

\section{Partial Test Results (t test) and Simultaneous (Test F)}

Testing the hypothesis aims to explain certain characteristics of the relationship or differences between groups or independence of two or more factors in a situation. Partial assay results aimed to test whether each independent variable significantly affect the dependent variable in part with $=0.05$ and also the acceptance or rejection of the hypothesis. Partial test ( $\mathrm{t}$ test) to answer a hypothetical one and two variables.

Table-3: T Test Results

\begin{tabular}{|l|l|r|r|}
\hline \multicolumn{2}{|c|}{ Model } & \multicolumn{1}{c|}{ t } & Sig. \\
\hline \multirow{2}{*}{1} & (Constant) & .623 & .539 \\
\cline { 2 - 4 } & DISCIPLINE & 2,781 & .010 \\
\cline { 2 - 4 } & COMMITMENT & 7244 & .000 \\
\hline
\end{tabular}

a. Dependent Variable: PERFORMANCE

To determine whether the independent variable in the regression model are positive and significant effect partially on the dependent variable, can be seen in the following explanation:
H1: Discipline has positive and significant effect on employee performance at UPI Convention Center Padang partially

- $\quad$ Ho = Discipline has no positive and significant effect on employee performance at UPI Convention Center Padang partially.

- $\quad \mathrm{Ha}=$ Discipline has positive and significant effect on employee performance at UPI Convention Center Padang partially.

Based on Table- 3 above it can be seen from the working Discipline variable t_count 2,781> 1,706 t_tabel and a significance level of $0.010<0.05$ or $\mathrm{Ho}$ refused and $\mathrm{Ha}$ is received, it can be stated variable Discipline has positive and significant effect on employee performance at UPI Convention Center Padang partially. This means that the first hypothesis is accepted.

H2: Commitment has positive and significant effect on employee performance at UPI Convention Center Padang partially

- Ho = Commitment has no positive and significant effect on employee performance at UPI Convention Center Padang partially.

- $\quad \mathrm{Ha}=$ Commitment has positive and significant effect on employee performance at UPI Convention Center Padang partially.

Based on Table- 3 above it can be seen from the discipline variable t_count 7.244> t_tabel 1.706 and 0.000 significance level $<0.05$ or Ho refused and $\mathrm{Ha}$ is received, it can be stated Commitment has positive and significant effect on employee performance at UPI Convention Center Padang partially. This means that the second hypothesis is accepted.

\section{Simultaneous Test (Test F)}

To determine whether the independent variable in the regression model (discipline and commitment) together influence the dependent variable (performance of employees), then used a statistical test F. 
Table-4: F Test Results (Simultaneous)

\begin{tabular}{|c|c|c|c|c|c|c|}
\hline \multicolumn{7}{|c|}{ ANOVAa } \\
\hline \multicolumn{2}{|r|}{ Model } & Sum of Squares & $\mathrm{df}$ & mean Square & $\mathrm{F}$ & Sig. \\
\hline \multirow[t]{3}{*}{1} & Regression & 724188 & 2 & 362094 & 41133 & $.000 \mathrm{~b}$ \\
\hline & residual & 237678 & 27 & 8803 & & \\
\hline & Total & 961867 & 29 & & & \\
\hline \multicolumn{7}{|c|}{ a. Dependent Variable: PERFORMANCE } \\
\hline \multicolumn{7}{|c|}{ b. Predictors: (Constant), COMMITMENT, DISCIPLINE } \\
\hline
\end{tabular}

H3: Discipline and commitment have positive and significant effect on employee performance at UPI Convention Center Padang simultaneously

- $\mathrm{Ho}=$ Discipline and commitment have no positive and significant effect on employee performance at UPI Convention Center Padang simultaneously.

- $\quad \mathrm{Ha}=$ Discipline and commitment have positive and significant effect on employee performance at UPI Convention Center Padang simultaneously.

Based on Table- 4 above in column $\mathrm{F}$ we get $\mathrm{F}$ count 41.133, the Sig column is the probability or significant value or significance $0.0000 \%$ with $\mathrm{F}$ table is 3.34. Test $\mathrm{F}$ : if $\mathrm{F}$ arithmetic $>\mathrm{F}$ table then $\mathrm{Ho}$ is rejected means significant, the results of the above analysis is 41.133> 3,34 hence Ho refused mean significant.

Based on the probability: if $<0.05$ then $\mathrm{Ho}$ is rejected, the results of its analysis $0.000<0.05$ means that Ho refused and $\mathrm{Ha}$ accepted. It can be concluded that Discipline and commitment have positive and significant effect on employee performance at UPI Convention Center Padang simultaneously. This means third hypothesis is accepted.

This study discussed about performance supported by previous research, among others: Aima [15], Riyanto [16], Agussalim [17], Ansori [13], Paijan [14], and Prayetno [18]. This study also discussed about discipline supported by previous research, among others: Suharyono [19] and Agussalim [17]. And it discussed about commitment supported by previous research, namely Prayetno [18].

\section{DISCUSSION}

This section contains a discussion of the influence of each independent variable that compensation and discipline of work to employees performance UPI convention center of Padang.

\section{Discipline Affects on Employee Performance}

Work discipline in the UPI convention center in Padang has a positive and significant effect on employee performance. The better employee discipline, the better the employee's performance. To improve employee performance through Discipline, what must be done by management are: employees can comply with regulations, must be active and present on time, always meet work hours, and always complete tasks on time.
Based on the results of testing the second hypothesis is known that the work discipline positive and significantly influence on employee performance at UPI convention center Padang. This is significant if the employees work discipline at UPI convention center Padang will be able to improve the employee performance of UPI convention center Padang will be better in the future. This is significant if further improved work discipline, it can improve employee performance at UPI convention center Padang. In other words, the increasing of employee discipline will affect the employee performance at UPI convention center Padang will be better in the future.

This research supports previous research including: 1) Alhudhori [20]; 2) Thaief [21]; and 3) Nugroho [22], where discipline has a positive and significant effect on employee performance.

\section{Commitment Affects on Employee Performance}

Commitment in UPI convention center in Padang has a positive and significant effect on employee performance. The better the commitment of employees, the better the performance of employees. To improve employee performance through commitment, what must be done by management are management must create a climate that cares for employees, and has responsibilities at work, employees have loyalty towards the work and enthusiasm to develop themselves in efforts to improve career.

Based on the results of testing the second hypothesis is known that commitment positive and significantly influence employee performance UPI convention center of Padang. The regression coefficient is positive indicating the occurrence of a unidirectional relationship organizational commitment to employee performance. This is significant if the organizational commitment of UPI Padang convention center is able to improve in the future so the performance of employees of UPI Padang convention center will be better in the future.

This research supports previous researches among others: 1) Koesmono [23]; 2) Atmojo [24]; and 3) Runi [25], where commitment has a positive and significant effect on employee performance.

\section{Discipline and Commitment affect on employee performance}

Discipline and Commitment in UPI convention center in Padang have a positive and significant effect on employee performance. The better discipline and 
commitment of employees, the better the performance of employees. To improve employee performance through Discipline, what must be done by management are: employees can comply with regulations, must be active and present on time, always meet work hours, and always complete tasks on time.

To improve employee performance through commitment, what must be done by management are management must create a climate that cares for employees, and has responsibilities at work, employees have loyalty towards the work and enthusiasm to develop themselves in efforts to improve career.

This research supports previous research including: 1) Alhudhori [20]; 2) Thaief [21]; and 3) Nugroho [22], where discipline has a positive and significant effect on employee performance. And also: 1) Koesmono [23]; 2) Atmojo [24]; and 3) Runi [25], where commitment has a positive and significant effect on employee performance.

\section{CONCLUSION AND SUGGESTION CONCLUSION}

The conclusions of the study are as follows:

- Work discipline in the UPI convention center in Padang has a positive and significant effect on employee performance. The better employee discipline, the better the employee's performance. To improve employee performance through Discipline, what must be done by management are: employees can comply with regulations, must be active and present on time, always meet work hours, and always complete tasks on time.

- Commitment in UPI convention center in Padang has a positive and significant effect on employee performance. The better the commitment of employees, the better the performance of employees. To improve employee performance through commitment, what must be done by management are management must create a climate that cares for employees, and has responsibilities at work, employees have loyalty towards the work and enthusiasm to develop themselves in efforts to improve career.

- Discipline and Commitment in UPI convention center in Padang have a positive and significant effect on employee performance. The better discipline and commitment of employees, the better the performance of employees. To improve employee performance through Discipline, what must be done by management are: employees can comply with regulations, must be active and present on time, always meet work hours, and always complete tasks on time. To improve employee performance through commitment, what must be done by management are management must create a climate that cares for employees, and has responsibilities at work, employees have loyalty towards the work and enthusiasm to develop themselves in efforts to improve career.

\section{SUGGESTION}

The results of this study are expected to provide benefits in the convention center UPI Padang. The suggestions can be submitted from the results of this study are as follows:

\section{For management UPI Convention Center}

- In an effort to achieve higher employee performance at UPI Convention Center Padang in the future, it is expected to pay attention to and improve work discipline.

- For organizational commitment, it is expected that the UPI Convention Center Padang attention to the following:

$>$ Giving the duties and responsibilities more challenging to employees so they can actualize capabilities as much as possible.

$>$ Increasing concern as employees so that the image UPI Padang convention center in the community is increasing.

$>$ Improve employee satisfaction by creating a conducive working environment. This can lead to the comfort atmosphere of the work that will increase employee loyalty to the convention center UPI Padang.

$>$ Perform self-development of employees with further studies and providing training that will improve the performance of employees

\section{For Further Research}

Here are suggestions for further research:

- To compare and reinforces the theory among the variables studied, or reviewing research needs to be done at another location in the same industry is tourism with bases in accordance with the MICE (meeting, incentive, convention, and exhibition).

- To learn more about the other variables that significantly affect the performance of employees in UPI Convention Center. Can be arranged so that the other models in solving problems related to employee performance will be improved.

- Further review is required to use or add other indicators and may also use different concepts. Other factors that affect the performance of employees other than the variables proposed in this study, such as: competence, promotion, transformational leadership style, training on work motivation, etc. Therefore, it is expected other factors can be studied so that the performance of employees at UPI Convention Center can be further improved and the development of science will be sustainable.

\section{REFERENCES}

1. Soedjono. (2005). Pengaruh Kepuasan kerja Terhadap Kinerja Karyawan dan Efektivitas 
Organisasi. Jurnal Ekonomi Management Fakultas Ekonomi, Universitas Kristen Petra.

2. Wibowo, S. (2012). Purification, and Biological Activity of AIB Substituted Glucagon and GLP-1 Peptide Analogues (2005-2006), 45, 707-738.

3. Mangkunegara, A. P., \& Prabu, A. (2009). Manajemen sumber daya manusia. Bandung: $P T$. Remaja Rosdakarya.

4. Nitisemito, A. S. (2002). Manajemen Personalia. Edisi Revisi, Penerbit Ghalia Indonesia.

5. Simamora, H. (2005). Manajemen Sumber Daya Manusia, Penerbit Andi, Yogyakarta.

6. Rival, T., Page, R. M., Chandraratna, D. S., Sendall, T. J., Ryder, E., Liu, B., ... \& Shearman, M. S. (2009). Fenton chemistry and oxidative stress mediate the toxicity of the $\beta$-amyloid peptide in a Drosophila model of Alzheimer's disease. European Journal of Neuroscience, 29(7), 1335-1347.

7. Allen, N. J., \& Meyer, J. P. (1990). The measurement and antecedents of affective, continuance and normative commitment to the organization. Journal of occupational psychology, 63(1), 1-18.

8. Porter, L. W., \& Steers, R. M. (1973). Organizational, work, and personal factors in employee turnover and absenteeism. Psychological bulletin, 80(2), 151176.

9. Arikunto, S. (2007). Prosedur Penelitian Suatu Pendekatan Pendekatan Praktik. Jakarta: Rineka Cipta.

10. Nawawi, H. (2007). Adimistrai Personalia untuk Meningkatkan Produktivita Kerja, Jakarta. Haji Mas agung.

11. Nasharr, A., Swanson, K., Chatz, B., Swinson, S., Reich, I., McCorkle, L., \& Schorling, W. B. (2007). Depaul Business \& Commercial Law Journal. Governance, 5(4).

12. Sugiyono. (2011). Penelitian Pendidikan Pendekatan Kualitatif dan R \& D. Bandung: Alfabeta.

13. Ansori, A., \& Ali, H. (2017). Analisis Pengaruh Kompetensi dan Promosi terhadap Kinerja Pegawai Negeri Sipil pada Sekretariat Daerah Kabupaten Bungo. Journal Ilmiah Universitas Batanghari Jambi, 15(1), 50-60.

14. Paijan, P., \& Ali, H. (2017). Pengaruh Gaya Kepemimpinan Transformasional, Pelatihan Terhadap Motivasi Kerja Serta Implikasi Kinerja Tenaga Kependidikan Di Universitas Mercu Buana Jakarta. Jurnal Ekonomi, 21(3), 343-359.

15. Aima, H., Adam, R., \& Ali, H. (2017). Model of Employee Performance: Competence Analysis and Motivation (Case Study at PT. Bank Bukopin, Tbk Center). Quest Journals-Journal of Research in Business and Management, 4(11), 49-59.
16. Riyanto, S., Sutrisno, A., \& Ali, H. (2017). The Impact of Working Motivation and Working Environment on Employees Performance in Indonesia Stock Exchange. International Review of Management and Marketing, 7(3), 342-348. Retrieved

from http://dergipark.org.tr/irmm/issue/32110/356036 5

17. Agussalim, M. P., Rezkiana, A., \& Ali, H. (2016). Analysis Work Discipline and Work Spirit toward Performance of Employees (Case Study Tax Office Pratama Two Padang). International Journal of Economics and Research. 13, 25412556.

18. Prayetno, S., \& Ali, H. (2017). Analysis of Advocates Organizational Commitment and Advocates Work Motivation to Advocates Performance and its Impact on Performance Advocates Office. International Journal of Economic Research.

19. Suharyono, S., \& Ali, H. (2017). Pengaruh Motivasi, Kedisiplinan dan Gaya Kepemimpinan terhadap Prestasi Kerja Pegawai pada Dinas Sosial Tenaga Kerja dan Transmigrasi Kabupaten Batang Hari. Jurnal Ilmiah Universitas Batanghari Jambi, 15(2), 78-86.

20. Alhudhori, M., \& Aldino, W. (2017). Pengaruh Kepemimpinan dan Disiplin Terhadap Motivasi Kerja Serta Dampaknya pada Kinerja Pegawai Rumah Sakit Umum Bersaudara Kabupaten Bungo. J-MAS (Jurnal Manajemen dan Sains), 2(1), 23-32.

21. Thaief, I., \& Baharuddin, A. (2015). Effect of training, compensation and work discipline against employee job performance. Rev. Eur. Stud., 7, 23.

22. Nugroho, S. (2017). Effect of Leadership, Working Dicipline and Working Environment on The Performance Through Motivation on the Tax Service Office of Pratama Surakarta. eAbstract Excellent, 2(2).

23. Koesmono, H. T. (2014). The influence of organizational culture, servant leadership, and job satisfaction toward organizational commitment and job performance through work motivation as moderating variables for lecturers in economics and management of private universities in east Surabaya. Educational Research International, 3(4), 25-39.

24. Atmojo, M. (2015). The influence of transformational leadership on job satisfaction, organizational commitment, and employee performance. International research journal of business studies, 5(2).

25. Runi, I., Ramli, M., Nujum, S., \& Kalla, R. (2017). Influence Leadership, Motivation, Competence, Commitment to Satisfaction and Performance Lecturer at Private Higher Education Kopertis Region IX In South Sulawesi Province. Journal of Business and Management, 19(7), 5667. 